\title{
GRB14 wt Allele
}

National Cancer Institute

\section{Source}

National Cancer Institute. GRB14 wt Allele. NCI Thesaurus. Code C52393.

Human GRB14 wild-type allele is located within 2q22-q24 and is approximately 129 kb in length. This allele, which encodes growth factor receptor-bound protein 14, is involved in the suppression of signaling from both the insulin receptor and the insulin-like growth factor receptor. 